\title{
ANAEROBIC DEGRADATION OF NONIONIC AND ANIONIC SURFACTANTS IN ENRICHMENT CULTURES AND FIXED-BED REACTORS
}

\author{
Stefan Wagener and Bernhard SChINK* \\ Fakultät für Biologie, Universität Konstanz, Postfach 5560, D-7750 Konstanz, \\ Federal Republic of Germany
}

\begin{abstract}
Anaerobic biodegradation and inhibitory effects of nonionic and anionic surfactants on methanogenic fermentation were tested in incubation experiments with anoxic sediment samples and sewage sludge. Alkylsulfonates and alkylbenzenesulfonates were not degraded but inhibited methanogenesis from sludge constituents at concentrations $\geqslant 10 \mathrm{mg} \mathrm{l}^{-1}$. Sodium dodecylsulfate was at least partly degraded after adaptation at concentrations $\leqslant 100 \mathrm{mg} \mathrm{l}^{-1}$ and the sulfate group was reduced to sulfide. The polyethyleneglycol moiety of alkylphenolethoxylates was fermented to methane at concentrations $\leqslant 500 \mathrm{mg} \mathrm{l}^{-1}$ whereas the alkylphenol residue probably remained unchanged. Alkylethoxylates were completely degraded to methane and $\mathrm{CO}_{2}$ at concentrations up to $1.0 \mathrm{gl}^{-1}$. Complete anaerobic degradation of this surfactant type to methane, $\mathrm{CO}_{2}$, and traces of acetate and propionate was demonstrated in a lab scale anaerobic fixed-bed reactor, either with prereduced mineral salts medium or with air-saturated artificial wastewater. This process lends itself as a suited, inexpensive means for treatment of wastewaters containing enhanced loads of nonionic surfactants, e.g. from the surfactant manufacturing or processing industry.
\end{abstract}

Key words -anionic surfactants, nonionic surfactants, wastewater treatment, methanogenesis, surfactant toxicity, anaerobic degradation, fixed-bed reactor

\section{INTRODUCTION}

Surface active agents such as nonionic and anionic surfactants reach domestic and industrial wastewater in increasing amounts. They often affect the efficiency of activated sludge plants by foaming in the aeration basin and reducing the settling properties of sludge flocs (Therien et al., 1984). These problems are of minor importance in plants treating only domestic wastewater with average surfactant concentrations of 1 to $10 \mathrm{mg} \mathrm{l}^{-1}$ (Hellmann, 1979). However, in wastewater originating from the surfactant manufacturing industry, concentrations increase up to $300 \mathrm{mg} \mathrm{l}^{-1}$ (pers. commun.). Direct purification of such wastewaters without dilution or aeration using an anaerobic treatment system provides several advantages if anaerobic biodegradation of these surfactants is possible at all.

Much work has been done to assess aerobic biodegradability and environmental safety of surfactants and their degradation products (Willets, 1973; Kravetz, 1981; Yamane et al., 1984). Aerobic biodegradability has been proven with the major types of surfactants such as linear alkylbenzenesulfonates (LAS) and alkylethoxylates (AEO) (Kimerle and Swisher, 1977; Turner et al., 1985; Steber and Wierich, 1985). Alkylphenolethoxylates (APEO) on

*Present address: Lehrstuhl Mikrobiologie I, Universität Tübingen, Auf der Morgenstelle 28, D-7400 Tübingen, Federal Republic of Germany. the other hand, are only incompletely degraded under aerobic as well as under anaerobic conditions, and persistent degradation products with hazardous influence on aquatic organisms accumulate (Giger $e t$ al., 1981; Stephanou and Giger, 1982).

Information on the anaerobic biodegradability of surfactants is scarce and so far limited to nonionics. AEO were partially degraded by an anaerobic marine bacterium, Pelobacter venetianus (Schink and Stieb, 1983) and also degradation of AEO in an anoxic lab scale digestor was recently reported (Steber and Wierich, 1984). The aim of the present study was to check the influence of nonionic and anionic surfactants on methanogenic digestion of complex organic matter, together with an assessment of their possible biodegradability. Also experiments on purification of wastewaters containing high loads of nonionic surfactants in a lab scale anaerobic fixed-bed reactor are reported.

\section{Surfactants}

Sodium dodecylbenzenesulfonate (LAS), sodium-dodecylsulfonate (AS) and sodiumdodecylsulfate (SDS) were obtained from EGA Chemie, Steinheim, F.R.G. Two surfactants of the polyoxyethylene alkyl ether type, Brij 35 (number of $C$ atoms in the alkyl chain $R=12$, average number of ethylene oxide units, $n=23$ ), E-LM 75 $(R=10-12, n=7.5)$ and one surfactant of the polyoxyethylene alkylphenyl ether type, E-N $90(R=10-12$, $n=9$ ) were obtained from Serva Chemie, Heidelberg (Brij 35) and AKZO Chemie, Düren, F.R.G. (E-LM 75, E-T 130, E-N 90). All surfactants were of technical purity. 


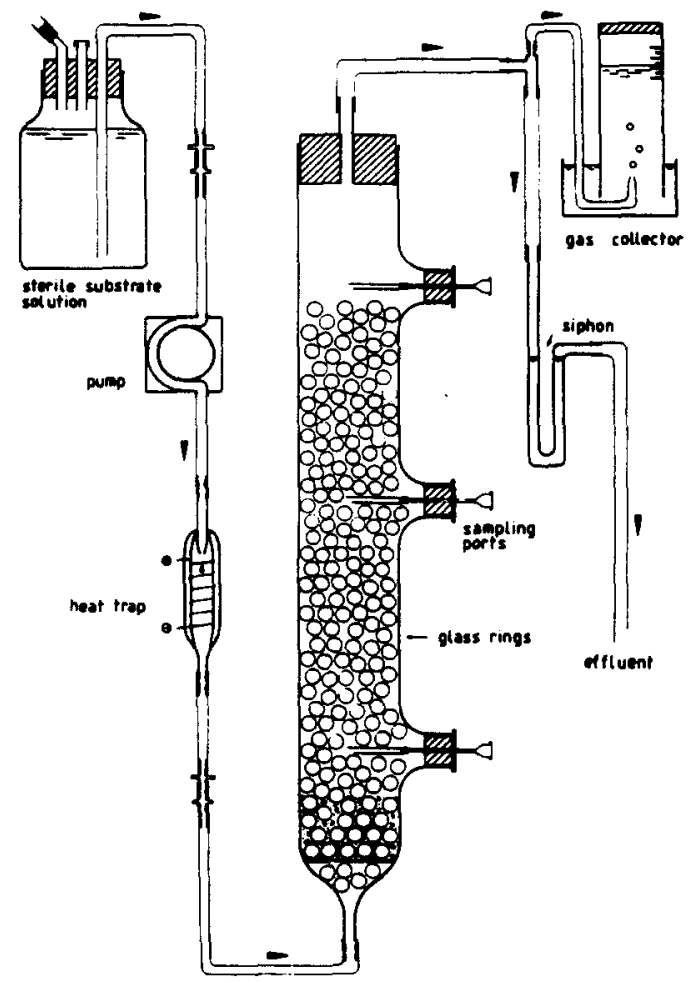

Fig. 1. Schematic diagram of the fixed-bed reactor. For details see text.

\section{Media and growth conditions}

Experiments were performed with either defined bicarbonate-buffered, sulfide-reduced medium as described previously (Schink and Pfennig, 1982; Tschech and Pfennig, 1984) or air-saturated synthetic wastewater.

Sterile synthetic wastewater had the following composition (values in $\mathrm{g}^{-1}$ ): peptone from casein, 0.16 ; meat extract, 0.11; urea, 0.03; $\mathrm{NaCl}, 0.007 ; \mathrm{CaCl}_{2} \cdot 2 \mathrm{H}_{2} \mathrm{O}, 0.004$; $\mathrm{MgSO}_{4} \cdot 7 \mathrm{H}_{2} \mathrm{O}, 0.02 ; \mathrm{CaCO}_{3}, 0.072$. The $\mathrm{pH}$ was adjusted to 7.8 . All experiments were carried out at $28^{\circ} \mathrm{C}$.

\section{Incubation experiments}

Anoxic sludge as inoculum for incubation experiments was obtained from the anoxic digestor of a municipal sewage plant and a polluted creek, both located near Konstanz, F.R.G. Experiments were performed in 25-ml serum bottles filled with a slurry of either $1.5 \mathrm{ml}$ digestor sludge or $1.5 \mathrm{ml}$ creek mud with $13.5 \mathrm{ml}$ reduced, buffered medium under an atmosphere of $\mathrm{N}_{2} / \mathrm{CO}_{2}(80 \% / 20 \%)$, and closed with butyl rubber stoppers.

Surfactants were added to the slurries from concentrated stock solutions. Control experiments were performed in the same way without surfactants but containing either $2 \mathrm{mM}$ lactate, $3 \mathrm{mM} \mathrm{SO}_{4}^{2-}$ or $2 \mathrm{mM}$ lactate plus $3 \mathrm{mM} \mathrm{SO}_{4}^{2-}$. The endogenous metabolic activity was determined by incubation of slurries without further additives. Methane production was measured at intervals during incubation, and sulfide and volatile fatty acids were determined at the end of incubation experiments after 33 days. All experiments were carried out in duplicates.

\section{Fixed-bed reactor experiments}

An anaerobic lab scale column reactor (Fig. 1) was set up using a glass column with lateral sampling ports. The total volume was $1000 \mathrm{ml}$ and the void volume $250 \mathrm{ml}$. The column was filled with "Sinter-glass"-rings (Schott, Mainz,
F.R.G.) with a porosity of about $60 \%$ and a high internal surface area $\left(0.2 \mathrm{~m}^{2} \mathrm{~g}^{-1}\right)$. Sterile medium or synthetic wastewater was pumped though the column from the bottom by a peristaltic pump (Minipuls, Gilson, Villiers le Bel, France) passing an electrically heated growth trap. Effluents left the reactor at the top and were separated by a siphon device. The liquid was collected in an effluent bottle, and the gas was quantified by displacement of a saturated $\mathrm{Na}_{2} \mathrm{SO}_{4}$-solution in an inverted graduated glass column.

\section{Start-up procedure}

The reactor was filled to one third with a mixture of reduced medium and $20 \mathrm{ml}$ anoxic digestor sludge. To improve microbial adsorption on the glass rings, the glass surface was coated with amorphous $F e S$ as described previously (Szewzyk and Pfennig, 1986). After complete filling the reactor was operated first as batch culture for 6 days. Afterwards, a semi-continuous operation was started pumping the medium for $3 \mathrm{~h}$ day $^{-1}$ which exchanged one-quarter of the void volume each time.

\section{Scanning electron microscope (SEM) preparation}

Sinter-glass rings taken from the reactor were prepared for scanning electron microscopy the following way:

Samples were fixed with $3 \%$ glutaraldehyde for $30 \mathrm{~min}$ at $20^{\circ} \mathrm{C}$. After washing for several times with distilled $\mathrm{H}_{2} \mathrm{O}$, samples were dehydrated in a series of increasing acetone concentrations (10-100\%), each for $10 \mathrm{~min}$. After "criticalpoint" drying, samples were coated with carbon, gold, and again with carbon, and viewed with a Philips SEM 505.

\section{Chemical analyses}

Sulfide was analyzed by the methylene blue method (Cline, 1969). Volatile fatty acids and methane were assayed by gas chromatography as previously described (Schink and Pfennig, 1982). Nonionic surfactants were quantified with phosphomolybdic acid by the method of Stevenson (1954).

\section{RESULTS}

\section{Incubation experiments}

Anoxic sludge from a digestor and a creek sediment showed significant endogenous $\mathrm{CH}_{4}$-production during 37 days of incubation with reduced, buffered mineral medium without further substrate additions. $\mathrm{CH}_{4}$-production during the incubation time is shown in Fig. 2(a) and (b) and was used as an indicator of the metabolic activity of the two sludges.

Addition of $2 \mathrm{mM}$ lactate increased considerably $\mathrm{CH}_{4}$-production and after 37 days $\mathbf{4 0} \%$ of the lactate in the digestor sludge and $80 \%$ of that in the creek sludge was fermented to methane. Addition of $2 \mathrm{mM}$ sulfate decreased $\mathrm{CH}_{4}$-production, and net 1.6 and $0.8 \mathrm{mM} \mathrm{H}_{2} \mathrm{~S}$ was formed in digestor sludge and creek sediment, respectively. $1.8 \mathrm{mM} \mathrm{H}_{2} \mathrm{~S}$ in digestor sludge and $1.1 \mathrm{mM} \mathrm{H}_{2} \mathrm{~S}$ in creek sludge was produced during incubation of $3 \mathrm{mM}$ lactate together with $2 \mathrm{mM}$ sulfate (data not shown). In these assays, total $\mathrm{CH}_{4}$-production was similar to that in the control assays [Fig. 2(a, b)].

Addition of nonionic or anionic surfactants to the slurries had quite different effects. Nonionic surfactant generally increased the $\mathrm{CH}_{4}$-production in both sludges. With creek sediment, all three nonionic surfactants increased $\mathrm{CH}_{4}$-production rates and 

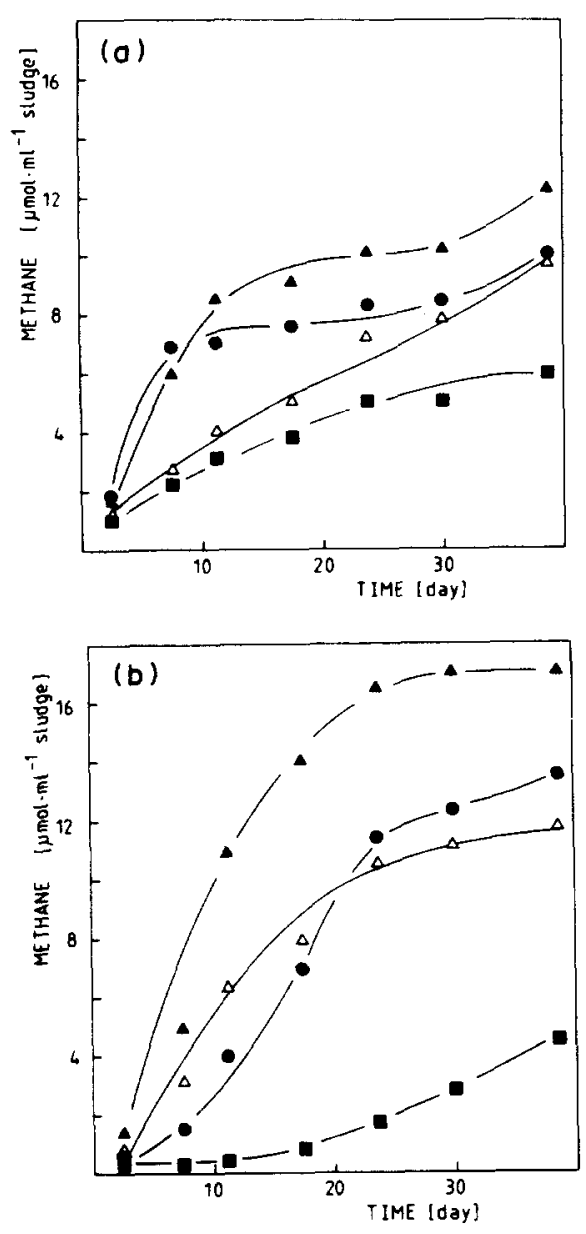

Fig. 2. Methane production during anaerobic incubation of (a) digestor sludge, (b) creek sludge. $\triangle$, no addition; addition of: $\mathbf{a}, 3 \mathrm{mM} \mathrm{SO}_{4}^{2-} ; \Delta, 2 \mathrm{mM}$ lactate;, $3 \mathrm{mM}$ $\mathrm{SO}_{4}^{2-}$ and $2 \mathrm{mM}$ lactate.

yields proportional to the amounts added [Table 1(b)].

Basically similar effects were observed with digestor sludge, but here the addition of E-LM 75 and E-N 90 caused increased methane production only after an adaptation time of 1-4 weeks [Table 1(a)]. After 37 days of incubation, small amounts of propionate had accumulated in assays with the highest amounts of nonionic surfactants. Only digestor sludge assays with $\lg 1^{-1}$ E-LM 75 and E-N 90 produced increased amounts of acetate [Table 1(a)].

Contrary to nonionic surfactants, anionics always had an inhibitory effect on sludge activity depending on the added amounts [Table 2(a,b)]. In creek sludge assays, the strongest inhibition was found during incubation with $0.57 \mathrm{~g}^{-1} \mathrm{SDS}, 0.54 \mathrm{~g}^{-1} \mathrm{AS}$, and $0.69 \mathrm{~g} \mathrm{t}^{-1}$ LAS. Concentrations of 0.1 and $0.01 \mathrm{~g} \mathrm{I}^{-1}$ had no significant effect on $\mathrm{CH}_{4}$-production, except for $0.1 \mathrm{~g}^{-1}$ AS [Table 2(b)].

In digestor sludge assays, strong inhibition was found with $0.57 \mathrm{gl}^{-1} \mathrm{SDS}, 0.54 \mathrm{gl}^{-1} \mathrm{AS}$, and
$0.69 \mathrm{~g} \mathrm{l}^{-1}$ LAS, as well (data not shown) but also $0.1 \mathrm{~g} \mathrm{I}^{-1}$ LAS reduced the total $\mathrm{CH}_{4}$-production significantly [Table 2(a)]. At $0.01 \mathrm{gl}^{-1}$ concentration anionic surfactants had no inhibitory effects on digestor sludge. Whenever methane production was inhibited by the presence of anionic surfactants, high amounts of acetate accumulated [Tabie 2(b)]. In assays with SDS additions, also $\mathrm{H}_{2} \mathrm{~S}$ production was increased as compared to the controls and the other surfactant assays.

\section{Fixed-bed reactor experiments}

The feasibility of a fixed-bed reactor for anaerobic treatment of wastewaters containing high loads of nonionic surfactants was studied in a column filled with sinter-glass rings. In a first series of experiments, a sulfide-reduced, carbonate-buffered mineral medium was applied which contained Brij 35 at $1 \mathrm{~g} \mathrm{I}^{-1}$ concn. After a "Start-Up" phase of 45 days (see "Experimental" section), no surfactant could be detected in the column effluent, and a continuous operation was started. The flow rate was $170 \mathrm{ml}$ day ${ }^{-1}$ corresponding to a void volume exchange rate of 1.5 day $^{-1}$.

Figure 3 shows the changes of $\mathrm{pH}$, fatty acid concentrations and $\mathrm{CH}_{4}$ production between days 45 and 68 of operation at the middle port and in the effluent of the column. During this time the concentration of Brij 35 in the effluent decreased from 5 to

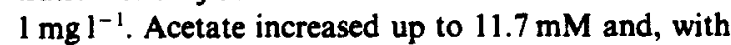
further operation time, decreased again to $5.7 \mathrm{mM}$. The concentrations of fatty acids at the middle part of the column and in the effluent did not differ significantly indicating that most of the bacterial activity was located in the lower part of the reactor. The propionate concentration was always lower than $2 \mathrm{mM}$, and $\mathrm{CH}_{4}$-production increased continuously during the operation time (Fig. 3).

After 70 days of operation, the flow rate was increased to $300 \mathrm{ml} \mathrm{day}^{-1}$. As a result, the remnant detergent concentration in the effluent increased to $20 \mathrm{mg} \mathrm{l}^{-1}$ but decreased continuously with time until no surfactant could be detected any more on day 90 . Figure 4 shows the changes of $\mathrm{pH}$, fatty acid concentrations and $\mathrm{CH}_{4}$ production between days 70 and 95 of operation. During this time, the methane pro-

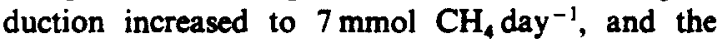
effluent acetate concentration decreased to $2.2 \mathrm{mM}$. The pH varied only between 6.8 and 6.9 .

The degradation efficiency was calculated via the electron balance according to the formula:

$$
\mathrm{C}_{58} \mathrm{H}_{118} \mathrm{O}_{24}+92 \mathrm{H}_{2} \mathrm{O} \rightarrow 58 \mathrm{CO}_{2}+302[\mathrm{H}] .
$$

The recovery of reducing equivalents $(H)$ in the fatty acids and methane produced for days $90-95$ of operation (Fig. 4) yields a degradation efficiency of $91.4 \%$. Without Brij 35 in the influent medium, no significant production of methane, acetate, or propionate was observed (data not shown). 
Table 1. Products formed during anaerobic incubation of (a) digestor sludge and (b) creek sludge with nonionic surfactants at various concentrations. All values are means of at least two independent experiments, ac: acetate. prop: propionate, but: butyrate

\begin{tabular}{|c|c|c|c|c|c|c|c|c|c|c|c|}
\hline \multirow[b]{3}{*}{$\begin{array}{l}\text { Surfactant } \\
\left.(\mathrm{g})^{-1}\right)\end{array}$} & & \multicolumn{10}{|c|}{ Incubation time (days) } \\
\hline & & 2 & 6 & 11 & 16 & 23 & 30 & 37 & \multicolumn{3}{|c|}{37} \\
\hline & & \multicolumn{7}{|c|}{$\mathrm{CH}_{4}\left(\mu \mathrm{mol} \mathrm{ml} \mathrm{m}^{-1}\right.$ sludge $)$} & ac & $\begin{array}{l}\text { prop } \\
(\mathrm{mM})\end{array}$ & but \\
\hline \multicolumn{2}{|l|}{ No addition } & 1.2 & 2.7 & 4.0 & 5.0 & 7.2 & 7.8 & 9.7 & 0.1 & 0.1 & - \\
\hline \multirow[t]{4}{*}{ Brij 35} & 1 & 1.6 & 3.9 & 5.8 & 9.1 & 42.1 & 55.0 & 64.5 & 0.1 & 0.6 & - \\
\hline & 0.5 & 2.1 & 7.7 & 27.2 & 35.4 & 35.7 & 35.6 & 36.1 & 0.1 & 0.2 & - \\
\hline & 0.1 & 2.1 & 7.8 & 8.6 & 9.4 & 11.7 & 11.7 & 12.1 & 0.1 & 0.2 & - \\
\hline & 0.01 & 1.3 & 2.7 & 4.2 & 5.4 & 7.5 & 8.2 & 11.0 & 0.1 & 0.1 & - \\
\hline \multirow[t]{4}{*}{ EL-LM 75} & 1 & 0.2 & 0.4 & 2.0 & 2.5 & 3.9 & 8.8 & 28.0 & 1.3 & 0.7 & 0.6 \\
\hline & 0.5 & 0.3 & 1.4 & 2.8 & 3.1 & 4.9 & 15.8 & 38.8 & 0.1 & 0.2 & - \\
\hline & 0.1 & 0.9 & 3.5 & 9.1 & 11.7 & 11.3 & 10.5 & 11.5 & 0.1 & 0.1 & - \\
\hline & 0.01 & 1.3 & 2.9 & 3.9 & 4.9 & 6.7 & 6.9 & 8.6 & 0.1 & 0.1 & - \\
\hline \multirow{4}{*}{ E-N 90} & 1 & 0.3 & 0.5 & 3.3 & 4.4 & 5.3 & 6.4 & 13.2 & 1.5 & 0.4 & - \\
\hline & 0.5 & 0.4 & 1.2 & 3.4 & 4.0 & 5.3 & 7.3 & 14.8 & 0.1 & 0.1 & - \\
\hline & 0.1 & 1.2 & 6.0 & 8.6 & 9.7 & 10.4 & 10.4 & 11.0 & 0.1 & 0.1 & - \\
\hline & 0.01 & 1.1 & 2.7 & 3.9 & 5.0 & 7.5 & 7.9 & 9.9 & 0.1 & 0.1 & - \\
\hline
\end{tabular}

(b)

\begin{tabular}{llllllllllll}
\hline No addition & & 0.8 & 3.1 & 6.3 & 7.9 & 10.5 & 11.1 & 11.7 & 0.1 & 0.1 & - \\
\hline Brij 35 & 1.0 & 1.0 & 7.8 & 11.1 & 17.3 & 34.2 & 50.6 & 58.5 & 0.1 & 0.6 & - \\
& 0.5 & 1.2 & 6.4 & 13.1 & 26.9 & 40.1 & 39.8 & 40.1 & 0.1 & 0.1 & - \\
& 0.1 & 1.5 & 5.7 & 11.1 & 13.4 & 15.9 & 16.4 & 17.6 & 0.1 & 0.1 & - \\
& 0.01 & 0.9 & 3.5 & 6.9 & 9.2 & 11.4 & 12.3 & 13.5 & 0.1 & 0.1 & - \\
E-LM 75 & 1.0 & 0.8 & 5.1 & 8.3 & 12.3 & 26.3 & 46.8 & 62.2 & 0.1 & 0.3 & - \\
& 0.5 & 0.8 & 4.1 & 8.2 & 15.9 & 35.4 & 39.2 & 40.1 & 0.1 & 0.1 & - \\
& 0.1 & 1.1 & 5.5 & 11.4 & 13.0 & 15.4 & 16.1 & 16.4 & 0.1 & 0.1 & - \\
& 0.01 & 1.1 & 3.6 & 6.9 & 8.5 & 11.3 & 12.3 & 13.5 & 0.1 & 0.1 & - \\
E-N 90 & 1.0 & 1.1 & 3.3 & 10.2 & 15.1 & 30.1 & 38.0 & 47.1 & 0.1 & 0.1 & - \\
& 0.5 & 1.0 & 4.8 & 9.4 & 16.9 & 27.5 & 32.2 & 32.5 & 0.1 & 0.1 & - \\
& 0.1 & 1.0 & 4.3 & 9.7 & 11.7 & 14.9 & 15.8 & 16.7 & 0.1 & 0.1 & - \\
& 0.01 & 0.9 & 3.2 & 6.4 & 8.2 & 10.7 & 11.3 & 12.0 & 0.1 & 0.1 & - \\
\hline
\end{tabular}

Table 2. Products formed during anaerobic incubation of (a) digestor sludge, (b) creek sludge with anionic surfactants at various concentrations. All values are means of at least two independent experiments, ac: acetate, prop: propionate, val: valerate

\begin{tabular}{|c|c|c|c|c|c|c|c|c|c|c|c|c|}
\hline \multirow{4}{*}{\multicolumn{2}{|c|}{$\begin{array}{l}\begin{array}{l}\text { Surfactant } \\
\left(\mathrm{g}^{-1}\right)\end{array} \\
\text { No addition }\end{array}$}} & \multicolumn{11}{|c|}{ Incubation time (days) } \\
\hline & & 2 & 6 & 11 & 16 & 23 & 30 & 37 & \multirow{2}{*}{ 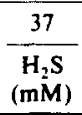 } & \multicolumn{3}{|c|}{37} \\
\hline & & \multicolumn{7}{|c|}{$\mathrm{CH}_{4}(\mu \mathrm{mol} \mathrm{m})^{-1}$ sludge $)$} & & ac & $\begin{array}{c}\text { prop } \\
\text { (mM) }\end{array}$ & val \\
\hline & & 1.2 & 2.7 & 4.0 & 5.0 & 7.2 & 7.8 & 9.7 & 0.4 & 0.1 & 0.1 & - \\
\hline SDS & $\begin{array}{l}0.1 \\
0.01\end{array}$ & $\begin{array}{l}0.6 \\
1.6\end{array}$ & $\begin{array}{l}1.7 \\
3.1\end{array}$ & $\begin{array}{l}5.3 \\
4.3\end{array}$ & $\begin{array}{l}8.6 \\
5.3\end{array}$ & $\begin{array}{r}10.1 \\
7.4\end{array}$ & $\begin{array}{r}10.1 \\
7.7\end{array}$ & $\begin{array}{r}11.0 \\
9.7\end{array}$ & $\begin{array}{l}0.7 \\
\text { ND }\end{array}$ & $\begin{array}{l}0.1 \\
0.1\end{array}$ & $\begin{array}{l}0.1 \\
0.1\end{array}$ & - \\
\hline AS & $\begin{array}{l}0.1 \\
0.01\end{array}$ & $\begin{array}{l}1.3 \\
1.0\end{array}$ & $\begin{array}{l}2.1 \\
1.9\end{array}$ & $\begin{array}{l}3.1 \\
3.1\end{array}$ & $\begin{array}{l}3.6 \\
3.8\end{array}$ & $\begin{array}{l}4.2 \\
5.6\end{array}$ & $\begin{array}{l}4.2 \\
6.1\end{array}$ & $\begin{array}{l}4.7 \\
9.1\end{array}$ & $\begin{array}{c}0.3 \\
\text { ND }\end{array}$ & $\begin{array}{l}0.1 \\
0.1\end{array}$ & $\begin{array}{l}0.1 \\
0.1\end{array}$ & - \\
\hline LAS & $\begin{array}{l}0.1 \\
0.01\end{array}$ & $\begin{array}{l}0.3 \\
1.1\end{array}$ & $\begin{array}{l}0.5 \\
2.3\end{array}$ & $\begin{array}{l}0.7 \\
3.8\end{array}$ & $\begin{array}{l}1.0 \\
4.8\end{array}$ & $\begin{array}{l}1.3 \\
6.9\end{array}$ & $\begin{array}{l}1.4 \\
7.0\end{array}$ & $\begin{array}{l}1.5 \\
7.9\end{array}$ & $\begin{array}{l}0.4 \\
\text { ND }\end{array}$ & $\begin{array}{l}1.9 \\
0.1\end{array}$ & $\begin{array}{l}0.2 \\
0.1\end{array}$ & - \\
\hline
\end{tabular}

(b)

\begin{tabular}{|c|c|c|c|c|c|c|c|c|c|c|c|c|}
\hline \multicolumn{2}{|c|}{ No addition } & \multirow{2}{*}{$\begin{array}{l}0.8 \\
0.1 \\
0.5 \\
1.1\end{array}$} & \multirow{2}{*}{$\begin{array}{l}3.1 \\
0.1 \\
2.2 \\
3.9\end{array}$} & \multirow{2}{*}{$\begin{array}{l}6.3 \\
0.1 \\
4.7 \\
7.6\end{array}$} & \multirow{2}{*}{$\begin{array}{r}7.9 \\
0.2 \\
7.2 \\
10.0\end{array}$} & \multirow{2}{*}{$\begin{array}{r}10.5 \\
0.6 \\
13.1 \\
13.2\end{array}$} & \multirow{2}{*}{$\begin{array}{r}11.1 \\
0.8 \\
14.0 \\
13.6\end{array}$} & \multirow{2}{*}{$\begin{array}{r}11.7 \\
0.8 \\
16.2 \\
14.8\end{array}$} & \multirow{2}{*}{$\begin{array}{l}1.8 \\
3.0 \\
2.0 \\
\text { ND }\end{array}$} & \multirow{2}{*}{$\begin{array}{l}0.1 \\
5.7 \\
0.1 \\
0.1\end{array}$} & \multirow{2}{*}{$\begin{array}{l}0.1 \\
0.3 \\
0.1 \\
0.1\end{array}$} & \multirow{2}{*}{$\begin{array}{l}- \\
1.0 \\
-\end{array}$} \\
\hline SDS & $\begin{array}{l}0.57 \\
0.1 \\
0.01\end{array}$ & & & & & & & & & & & \\
\hline AS & $\begin{array}{l}0.54 \\
0.1 \\
0.01\end{array}$ & $\begin{array}{l}0.6 \\
0.7 \\
1.0\end{array}$ & $\begin{array}{l}1.4 \\
1.8 \\
3.4\end{array}$ & $\begin{array}{l}2.1 \\
2.8 \\
5.8\end{array}$ & $\begin{array}{l}2.5 \\
3.7 \\
8.2\end{array}$ & $\begin{array}{r}2.9 \\
5.1 \\
10.4\end{array}$ & $\begin{array}{r}2.9 \\
5.7 \\
11.1\end{array}$ & $\begin{array}{r}2.9 \\
6.1 \\
11.9\end{array}$ & $\begin{array}{r}1.4 \\
1.4 \\
\text { ND }\end{array}$ & $\begin{array}{l}2.5 \\
1.1 \\
0.1\end{array}$ & $\begin{array}{l}0.5 \\
0.2 \\
0.1\end{array}$ & $\begin{array}{l}- \\
-\end{array}$ \\
\hline LAS & $\begin{array}{l}0.69 \\
0.1 \\
0.01\end{array}$ & $\begin{array}{l}0.3 \\
0.8 \\
1.1\end{array}$ & $\begin{array}{l}0.5 \\
2.2 \\
3.9\end{array}$ & $\begin{array}{l}0.7 \\
4.5 \\
7.7\end{array}$ & $\begin{array}{l}0.7 \\
6.4 \\
9.9\end{array}$ & $\begin{array}{r}0.7 \\
9.1 \\
12.9\end{array}$ & $\begin{array}{r}0.7 \\
10.6 \\
13.9\end{array}$ & $\begin{array}{r}0.7 \\
12.6 \\
15.2\end{array}$ & $\begin{array}{l}1.7 \\
2.2 \\
\text { ND }\end{array}$ & $\begin{array}{l}1.8 \\
0.2 \\
0.1\end{array}$ & $\begin{array}{l}0.4 \\
0.1 \\
0.1\end{array}$ & $\begin{array}{l}- \\
-\end{array}$ \\
\hline
\end{tabular}

$\mathrm{ND}=$ not determined 


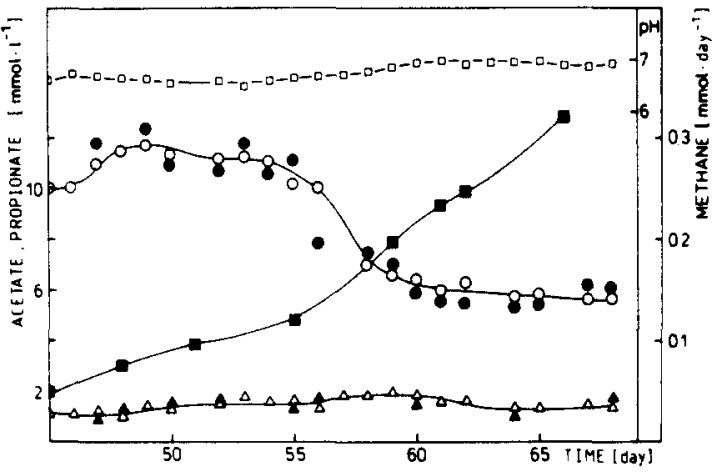

Fig. 3. Products formed during anaerobic degradation of $1 \mathrm{gl}^{-1}$ Brij 35 in a fixed-bed reactor between days 45 and 68 of operation. Flow rate: $170 \mathrm{ml}$ day $^{-1}$, acetate $(O)$, propionate $(\triangle), \mathrm{pH}(\square)$ in the mid; acetate $(\Theta)$, propionate

$(A)$ in the effluent of the reactor; methane $(\mathbb{D})$.

\section{BACTERIAL POPULATIONS IN THE REACTOR}

The bacterial populations involved in detergent degradation in the column reactor were examined by phase contrast microscopy of the effluent liquid and by scanning electron microscopic observation of the sinter-glass rings. In the effluent liquid, flocs of bacteria similar to Methanothrix soehngenii were found together with short Gram-negative and Grampositive rods. Glass spools for SEM preparation were taken after 93 days of operation. In the lower part of the column, a heterogenous bacterial population established (Fig. 5) consisting of long, filamentous bacteria and short rods of various sizes. In the upper part nearly exclusively long filamentous bacteria were observed (Fig. 6) which resembled $M$. soehngenii, an acetate-fermenting methane bacterium. These results demonstrate a spatial separation of degradation pro-

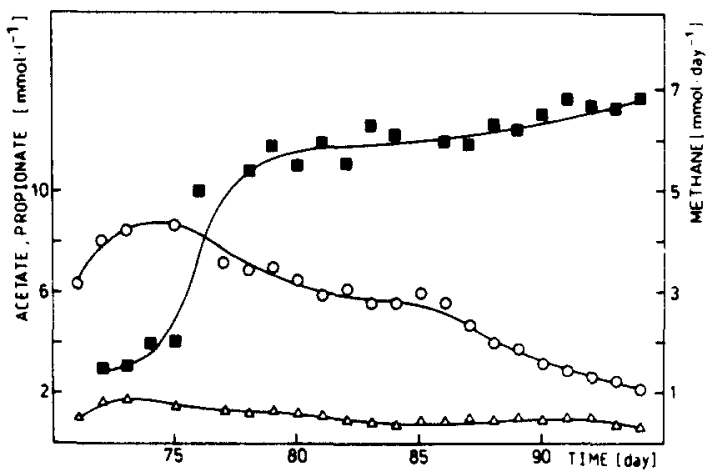

Fig. 4. Products formed during anaerobic degradation of $1 \mathrm{~g}^{-1}$ Brij 35 in a fixed-bed reactor between days 70 and 95 of operation. Flow rate: $300 \mathrm{ml} \mathrm{day}^{-1}$, acetate $(0)$, propionate $(\Delta)$ in the effluent of the reactor; methane (D).

cesses in the reactor: whereas in the lower part mainly surfactants were degraded to acetate, in the upper part acetate was converted to methane.

\section{EXPERIMENTS WITH SYNTHETIC WASTEWATER}

A further reactor experiment was started to check whether the observed anaerobic degradation of a nonionic surfactant can also take place in airsaturated synthetic wastewater. The column setup was the same as in the first set of experiments (Fig. 1). Brij 35 was added to synthetic wastewater at a concentration of $100 \mathrm{mg} \mathrm{l}^{-1}$.

After a batch incubation phase of 3 days, continuous flow was started with an influent rate of $115 \mathrm{ml} \mathrm{day}^{-1}$. After 8 days of continuous operation, no surfactant could be detected in the column effluent. The acetate concentration decreased from

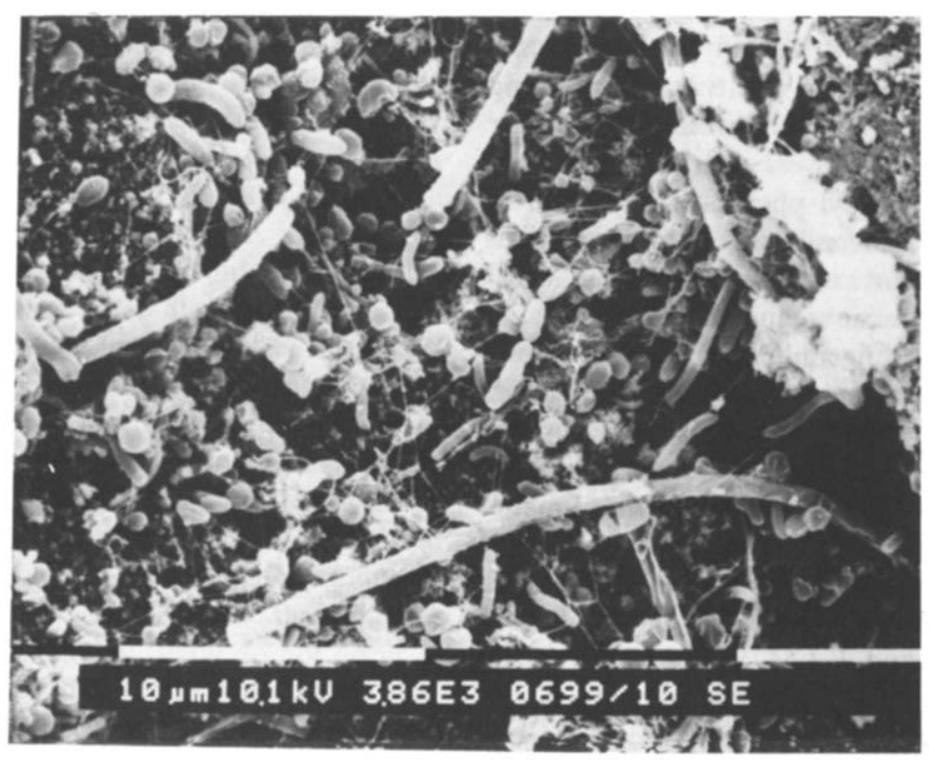

Fig. 5. Scanning electron micrograph of the bacterial population at the surface of a sinter-glass ring in the lower part of a fixed-bed reactor. Bar equals $10 \mu \mathrm{m}$. 


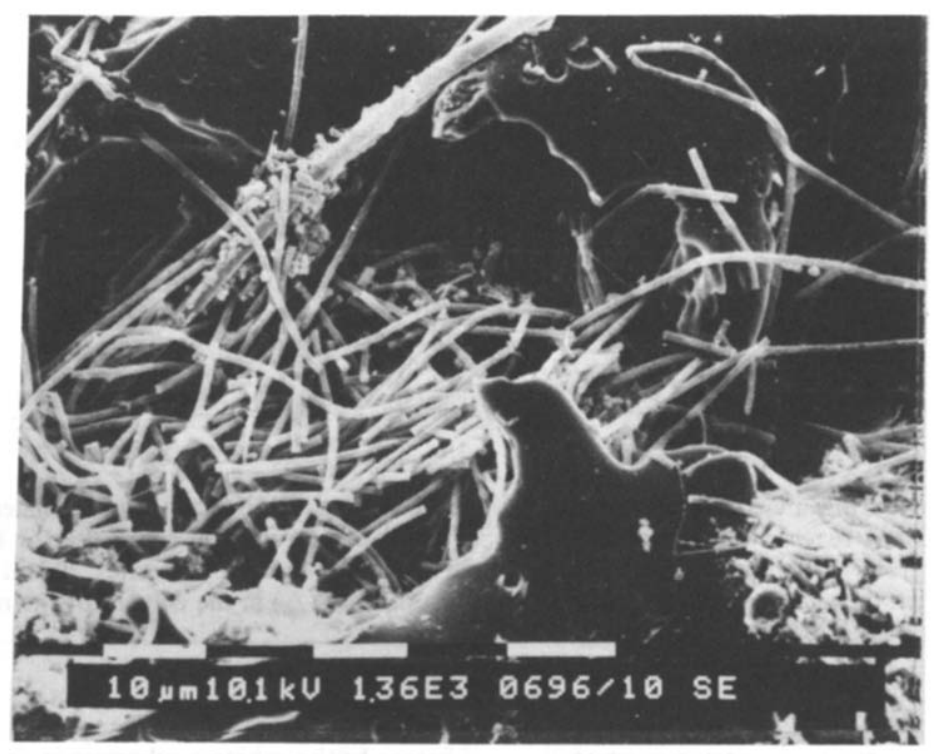

Fig. 6. Scanning electron micrograph of bacterial cells at the surface of a sinter-glass ring in the upper part of a fixed bed reactor. Bar equals $10 \mu \mathrm{m}$.

0.78 to $0.07 \mathrm{mM}$ after 14 days of operation (Fig. 7). After 10 days also the propionate concentration decreased, and gas was produced at a rate of $0.6 \mathrm{mmol} \mathrm{CH}_{4} \mathrm{I}^{-1}$. In this reactor, the same types of bacteria established as in the first column (Figs 5 and 6).

\section{DISCUSSION}

The effects of surfactants on living cells are very complex and include penetration of the membrane and its fluidization, in hand with partial solubilization of structural components (Florence et al., 1984). Toxicity of surfactants was reported for a broad variety of organisms, including fish, algae, and bacteria (Yamane et al., 1984; Kimerle and Swisher, 1977; Florence et al., 1984). Usually surfactants are degraded in sewage treatment plants before reaching natural waters (Willets, 1973; Kravetz, 1981; Steber and Wierich, 1985). However, degradation is not always complete, and alkyl phenols highly toxic to fish and small water invertebrates may be formed during aerobic treatment and especially during anaerobic diagenesis in anoxic sediments (Giger et al., 1981; Stephanou and Giger, 1976).

Our experiments with anionic and nonionic surfactants showed that the various types of surfactants had quite different effects on fermentation processes in anoxic sludge. Nonionic surfactants enhanced methane production during incubation with anoxic sediment indicating at least partial biodegradation. In creek sludge assays, 80 and $70 \%$ of the alkylethoxylates Brij 35 and E-LM75 was converted to methane after 37 days of incubation. In contrast, the alkylphenolethoxylate E-N90 exhibited only partial conversion $(45-50 \%)$ to methane, probably because only the polyethyleneglycol residue was degraded.
The alkylphenol residue of alkylphenolethoxylates is released under anaerobic conditions, and appears to not undergo any further significant degradation, neither in the presence nor in the absence of oxygen (Giger et al., 1981; Stephanou and Giger, 1982; Giger, pers. commun.). Basically the same effects were observed during incubation of nonionic surfactants with digestor sludge. This sludge was more sensitive to higher surfactant additions and needed comparably long adaption times before methanogenic surfactant degradation started. One $\mathrm{gl}^{-1}$ E-LM75 and also $1 \mathrm{gl}^{-1}$ E-N90 inhibited the methanogenic activity but allowed some fermentation processes leading to the accumulation of fatty acids.

Contrary to nonionics, anionic surfactants always impaired methane formation in incubation experi-

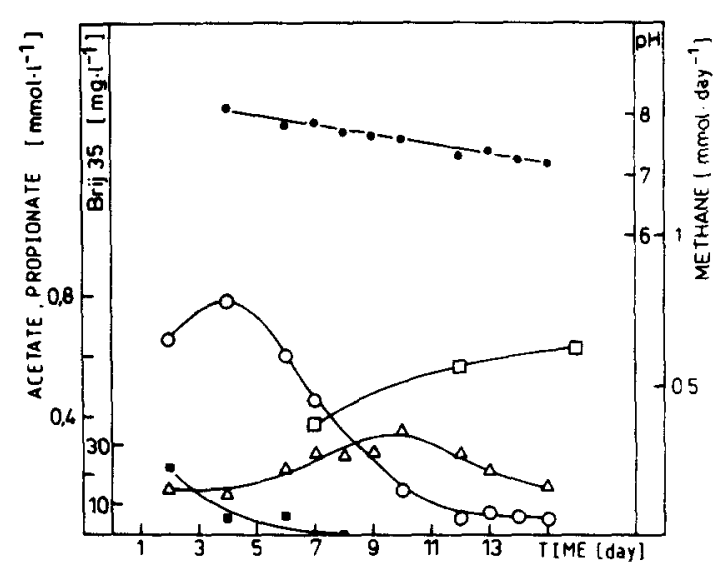

Fig. 7. Products formed during operation of a fixed-bed reactor with air-saturated synthetic wastewater containing $0.1 \mathrm{~g} \mathrm{I}^{-1}$ Brij 35. Flow rate: $115 \mathrm{ml} \mathrm{day}^{-1}$, acetate $(\mathrm{O})$, propionate $(\triangle)$, Brij $35(\square)$, pH $(O)$ in the effluent of the reactor; methane $(\square)$. 
ments with sediment and sludge samples. Inhibition of methane formation was always associated with accumulation of acetate. Since acetate cleavage usually accounts for $60-70 \%$ of the total methane formation in neutral anoxic environments (Lawrence and McCarty, 1969; Schink, 1985; Kaspar and Wuhrmann, 1978) both acetate accumulation and inhibition of methanogenesis can be explained by a direct toxic effect on the acetate-cleaving methanogens (Hanaki et al., 1981). However, it could also be that hydrogen-oxidizing methanogens are inhibited and that homoacetogenic anaerobes take over as this was observed to occur e.g. in slightly acidic sediments (Phelps and Zeikus, 1984).

In incubation experiments with sodium dodecylsulfate (SDS), always a marked increase in sulfide formation was observed. Since the sulfate residue of SDS was the only external sulfur source in these experiments, and sulfate reduction begins with a rather complicated activation reaction (Postgate, 1983 ) it has to be assumed that sulfate is first released from the SDS molecule by hydrolytic cleavage. An alkylsulfatase enzyme able to cleave SDS was so far described only for an aerobic Pseudomonas strain (Humphreys et al., 1986). No increased sulfide formation was observed in the incubations with alkylsulfonates and alkylbenzene sulfonates, and no indication of degradation of the carbon skeleton of these compounds was found. These results suggest that these surfactants are not degraded at all under anaerobic conditions. Desulfonation of alkylsulfonates was so far only observed with aerobic bacteria, and probably required molecular oxygen as a reactant in an oxygenase reaction (Payne and Feisal, 1963; Cain and Farr, 1968).

High amounts of acetate together with valerate and propionate accumulated in incubation experiments with SDS and indicates at least partial degradation of the dodecanol residue. This is of environmental importance since an accumulation of fatty acids in the range of 8-12 carbon atoms can strongly inhibit anaerobic degradation processes (Hanaki et al., 1986). It is not clear yet how odd-numbered fatty acids arise during degradation of a C-12 alcohol. They could form from $\mathrm{C}_{2}$ compounds and $\mathrm{CO}_{2}$ by secondary reductive processes (Schink, 1984).

It can be summarized that alkylethoxylates and alkylsulfates can be degraded completely in the absence of oxygen whereas partial degradation of alkylphenol ethoxylates leads to an accumulation of toxic alkylphenols, and alkylsulfonates and alkylbenzene sulfonates are not degraded at all. All anionic surfactants inhibited methanogenesis at concentrations $\geqslant 100 \mathrm{mg} \mathrm{l}^{-1}$, but the susceptibility to this inhibition differed between the sludge types tested. Although surfactants usually do not occur at these concentrations in domestic wastewater, they are common in special wastewaters released by the surfactant producing and processing industry. We therefore explored whether surfactants at this con- centration range and higher can be degraded by anaerobic treatment.

Biodegradation of $1 \mathrm{~g}^{-1}$ Brij 35 was studied in a lab scale fixed bed reactor. Under optimal growth conditions, i.e. using a reduced, buffered mineral medium, the substrate was degraded completely and more than $90 \%$ of the substrate electrons was recovered as methane, acetate, and propionate in the column effluent. Since usually about $5-10 \%$ of the substrate is assimilated into cell material, the fermentation stoichiometry can be considered as almost complete. Brij 35 degradation occurred as well in air-saturated synthetic wastewater. Our experiments showed that the complex microbial community which developed in these columns from a sewage sludge inoculum was able to create and maintain in the column anaerobic conditions sufficient to allow methanogenic substrate degradation to occur. Acetate and propionate appeared at low concentrations as byproducts of surfactant degradation. High populations of Methanothrix sp. and a constantly low propionate level $(\leqslant 0.2 \mathrm{mM})$ indicate that both fatty acids are being degraded continuously (Boone and Bryant, 1980; Koch et al., 1983). Therefore, the ultimate biodegradation of high amounts of alkylethoxylates in a fixed bed reactor to $\mathrm{CH}_{4}$ and $\mathrm{CO}_{2}$ appears to be possible.

Using an anaerobic treatment system for wastewaters containing high loads of surfactants provides several advantages in comparison to an activated sludge system. Organic freights can be treated and methane is recovered which is of increasing benefit considering rising energy prices. So far, anaerobic wastewater treatment systems have mainly been applied for industrial wastewaters with very high loads of easily degradable organic constituents (Wandrey and Aivasidis, 1983; Switzenbaum, 1983). Our experiments demonstrate that this approach is also feasible with comparably low freights of substrates if these would present specific problems in conventional aerobic treatment, e.g. by excessive foaming.

It has to be realized, however, that industrial wastewaters usually do not contain one single type of surfactant but mixtures of several types at varying concentrations. Since the biodegradability of these various types differs considerably, and anionic surfactants may detrimentally affect methanogenic degradation of e.g. nonionics, the applicability of the anaerobic fixed-bed treatment presented in this paper may be limited in industrial waste disposal by the possibilities to separate various surfactant types in the wastewater system. In our experience, nonionic alkylethoxylates provided the least difficulties with anaerobic biodegradation and should be preferred over the other types on a long time scale wherever possible.

Acknowledgements-The authors are greatly indebted to Professor Dr N. Pfennig for support and valuable discussions. Thanks are also due to Schott Glass Co., Mainz, for providing the sinter-glass ring material used. 


\section{REFERENCES}

Boone D. R. and Bryant M. P. (1980) Propionate-degrading bacterium, Syntrophobacter wolinii sp. nov. gen. nov., from methanogenic ecosystems. Appl. envir. Microbiol. 40, 626-632.

Cain R. B. and Farr D. R. (1968) Metabolism of arylsulphonates by micro-organisms. Biochem. J. 106, 859-871.

Cline J. D. (1969) Spectrophotometric determination of hydrogen sulfide in natural waters. Limnol. Oceanogr. 14, 454-458.

Florence A. T., Tucker J. G. and Walkers K. A. (1984) Interactions of nonionic polyethylene alkyl and arylethers with membranes and other biological systems. In Structure/Performance Relationship in Surfactants (Edited by Rosen M. J.), pp. 188-207. ACS Symposium Series 253, American Chemical Society, Washington, D.C.

Giger W. E., Stephanou E. and Schaffner C. (1981) Persistent organic chemicals in sewage effluents-I. Identifications of nonylphenols and nonylphenolethoxylates by glass capillary gas chromatography/mass spectrometry. Chemosphere 10, 1254-1263.

Hanaki K., Matsuo T. and Nagase M. (1981) Mechanism of inhibition caused by long-chain fatty acids in anaerobic digestion process. Biotechnol. Bioengng 23, 1591-1610.

Hellmann H. (1979) Zur Bestimmung von nichtionischen Tensiden in Wasser und Abwasser durch Röntgenfluoreszenz und JR-Spektroskopie. Z. analyt. Chem. 297, 102-106.

Humphreys P. G. M., Shaw D. J., Dodgson K. S. and White G. F. (1986) Concerted induction of the S3 alkylsulphatase of Pseudomonas $\mathrm{Cl} 2 \mathrm{~B}$ by combinations of alkyl sulphate and alcohols. J, gen. Microbiol. 132 , 727-736.

Kaspar H. F. and Wuhrmann K. (1978) Kinetic parameters and relative turnovers of some important catabolic reactions in digesting sludge. Appl. envir. Microbiol. 36, I-7.

Kimerle R. A. and Swisher R. D. (1977) Reduction of aquatic toxicity of linear alkylbenzene sulfonate (LAS) by biodegradation. Wat. Res. 11, 31-37.

Koch M., Dolfing I., Wuhrmann K. and Zehnder A. J. B (1983) Pathways of propionate degradation by enriched methanogenic cultures. Appl. envir. Microbiol. 45, 1411-1414.

Kravetz L. (1981) Biodegradation of nonionic ethoxylates. J. Am. Oil Chem. Soc. 58, 58-65.

Lawrence A. W. and McCarty P. L. (1969) Kinetics of methane fermentation in anaerobic treatment. $J$. Wat. Pollut. Control. Fed. 41, 1-17.

Payne W. J. and Feisal V. E. (1963) Bacterial utilization of dodecylsulfate and dodecylbenzene sulfonate. Appl. Microbiol. 11, 339-344.

Pheips T. J. and Zeikus J. G. (1984) Influence of pH on terminal carbon metabolism in anoxic sediments from a mildly acidic lake. Appl. envir. Microbiol. 48, 1088-1095.
Postgate J. R. (1983) The Sulphate-Reducing Bacteria, 2nd edition. Cambridge University Press.

Schink B. (1984) Fermentation of 2, 3-butanediol by Pelobacter carbinolicus sp. nov. and Pelobacter propionicus sp. nov., and evidence for propionate formation from C,-compounds. Arch. Microbiol. 137, 33-41.

Schink B. (1985) Mechanisms and kinetics of succinate and propionate degradation in anoxic freshwater sediments and sewage sludge. J. gen. Microbiol. 131, 643-650.

Schink B. and Pfennig N. (1982) Fermentation of trihydroxybenzenes by Pelobacter acidigallici gen. nov. sp. nov., a new, strictly anaerobic, non-sporeforming bacterium. Arch. Microbiol. 133, 195-201.

Schink B. and Stieb M. (1983) Fermentative degradation of polyethyleneglycol by a strictly anaerobic, gram-negative. nonsporeforming bacterium. Pelobacter venetianus sp. nov. Appl. envir. Microbiol. 45, 1905-1913.

Steber I. and Wierich P. (1984) Der anaerobe Abbau von ${ }^{14} \mathrm{C}$-markierten Fettalkoholethoxylaten. In Proceedings of World Surfactants Congress, 6-10 May 1984. Munich, pp. 176-187. Kürle Druck, Gelnhausen.

Steber J. and Wierich P. (1985) Metabolites and biodegradation pathways of fatty alcohol ethoxylates in microbial biocenoses of sewage treatment plants. Appl. envir. Microbiol. 49, 530-537.

Stephanou E. and Giger W. (1982) Persistent organic chemicals in sewage effluent-II. Quantitative determinations of nonylphenols and nonylphenol ethoxylates by glass capillary gas chromatography. Envir. Sci. Technol. 16, 800-805.

Stevenson D. G. (1954) The absorptiometric determination of a nonionic detergent. Analyst (Lond.) 79, 504-507.

Switzenbaum M. S. (1983) Anaerobic treatment of wastewater; recent developments $A S M$-News 49, 532-536.

Szewzyk U. and Pfennig N. (1986) A simple method for enrichment and cultivation of anaerobic surfacecolonizing bacteria. J. Microbiol. Meth. 5, 289-294.

Therien N., Le Calve P. and Jones P. (1984) A respirometric study of the influence of aliphatic alcohols on activated sludge. Wat. Res. 18, 905-910.

Turner A. H., Abram F. S., Brown V. M. and Painter H. A. (1985) The biodegradability of two primary alcohol ethoxylate nonionic surfactants under practical conditions, and the toxicity of the biodegradation products to Rainbow trout. Wat. Res. 19, 45-51.

Tschech A. and Pfennig N. (1984) Growth yield increase linked to caffeate reduction in Acetobacterium woodii. Arch. Microbiol. 137, 163-167.

Wandrey L. and Aivasidis A. (1983) Zur Reaktionstechnik der anaeroben Fermentation. Chemie-Ingr-Tech. 55, 516-524.

Willetts A. J. (1973) Microbial aspects of the biodegradation of synthetic detergents: a review. Int. Biodetn. Bull. 9 , 3-10.

Yamane A. N., Okado M. and Sudo R. (1984) The growth inhibition of planktonic algae due to surfactants used in washing agents Wat. Res. 18, 1101-1105. 